any assessment of their usefulness or validity in a clinical setting.

The omission is notable given that Ed McCabe chaired the US Department of Health and Human Services Advisory Committee on Genetic Testing during its evaluation of genetic testing oversight. This committee concluded that government regulation was inadequate and put forth a series of policy recommendations. Because none of these recommendations was adopted, the issue still looms large - both for genetics and geneticists, and for medicine more broadly.

Good guidebooks should point out new attractions as well as old, and new texts ought to cover contemporary issues as well as the historical. Neither the McCabes nor Barash accomplish this - both books are rooted in past discourses and ignore current issues of greater public health and policy urgency.

Kathy Hudson is director of the Genetics and Public Policy Center, Johns Hopkins University, 1717 Massachusetts Avenue NW, Washington DC 20036, USA.

\title{
The cost of vague patents
}

\section{Patent Failure: How Judges, Bureaucrats, and Lawyers Put Innovators at Risk by James Bessen and Michael J. Meurer Princeton University Press: 2008. 352 pp. $\$ 29.95, £ 17.95$}

Adding fuel to the anti-patent fire, James Bessen and Michael Meurer argue in Patent Failure that US patents cost more than they should because their claims are too vague. Patent claims define the scope of a patented invention, and when they are unclear, competitors cannot determine whether or not they are infringing the patent and whether they should license or litigate.

Bessen and Meurer argue that 'fuzzy' claims for abstract inventions such as software, biotechnology and business methods make patents too expensive to society. Chemical and pharmaceutical patents, however, produce net economic benefits, as do patents obtained by small companies.

The authors spend most of their energy attacking software patents, describing skyrocketing litigation costs, increasing uncertainty, the thousands of patents on a single product, and other problems that hinder software innovation. They ask why the system works more poorly for software and biotechnology companies than for pharmaceuticals and chemicals. Their research leads the authors to posit several explanations. First, claims on small molecules are clearer and more comprehensible than the abstract claims in

\section{biotechnology and software patents.}

Second, the US Patent and Trademark Office (USPTO) and courts unwisely permit 'premature' patent claims on biotechnology and software products that have not and cannot yet be made. For example, Amgen's patent on a method of making the red-bloodcell protein erythropoietin in hamster cells claimed all "non-naturally occurring" erythropoietin, including that made in human cells, even though erythropoietin had not yet been made that way.

Third, the courts have allowed patenting of early-stage biotechnology and software inventions that remain inchoate and abstract, increasing the likelihood of litigation against someone who independently develops an invention that falls within the scope of a patent claim. Fourth, patent law is in flux for the new fields of biotechnology and software. By contrast, organic chemistry is more than a century old, so the boundaries of patent claims are written clearly enough for competitors to understand what is claimed and what is not. Thus, companies can avoid infringement or resolve disputes quickly. Finally, the authors blame judges for expansionist tendencies that lead them to allow patents on "everything under the sun made by man", resulting in a flood of biotechnology and software patents.

Bessen and Meurer use a lively, assertive style and are critical of patent-system stakeholders, including federal judges, the USPTO and patent lawyers. Throughout the book, they contrast the patent system's rules about claim boundaries with the supposed success of realestate law, a system that has clear, surveyed and publicly available land boundaries.

In the late 1990s, the authors contend, the US patent system failed publicly traded corporations. They estimate that the cost to such businesses of litigation over chemical and pharmaceutical patents was around $\$ 4$ billion in 2000, but this was more than outweighed by the profits associated with patents of about $\$ 15$ billion, a questionably low number given the value of blockbuster drugs. But for other industries, litigation costs were about $\$ 12$ billion and the profit was only about $\$ 3$ billion, also a questionably low number, and a net social loss. The authors recognize that owning patents always provides a competitive advantage for individual companies, even if the overall industry would be better off without them.

The authors offer several suggestions. Force inventors to clarify ambiguous claims with the USPTO. Convince judges to invalidate claims that are not definite and clear. Empower the

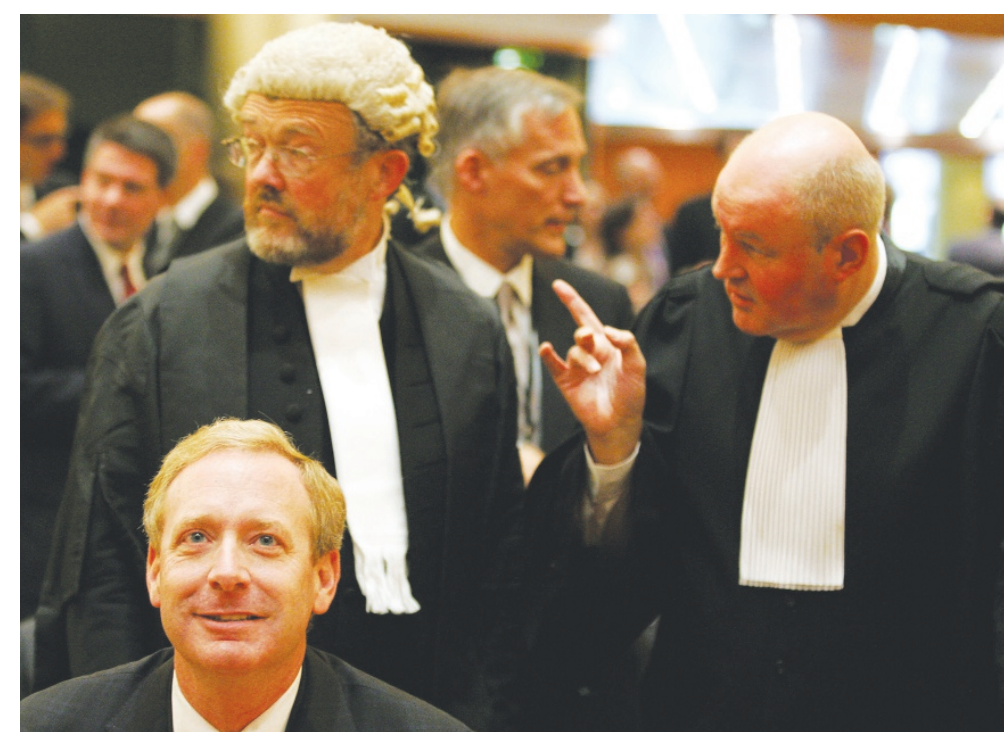

Microsoft's legal chief Brad Smith (bottom left) and lawyers wait for a 2007 decision at the European Union court that fined the company over expensive patent licences. USPTO to give pre-litigation opinions on claim scope and infringement. Increase renewal fees to prune out unused patents. Establish a prior user defence so that independent discovery and use of a patented invention is not considered infringement.

Admirably, Bessen and Meurer reject what they call "faith-based policy" based on unsubstantiated beliefs about how patents help or hurt different companies and industries. Instead, they aim to provide the "first comprehensive empirical evaluation of the patent system's performance". They do well with studies of famous patent disputes, such as Kodak versus Polaroid (regarding instant 
photography) and NTP versus Research in Motion (regarding the BlackBerry wireless device). Unfortunately, the book's strength - its reliance on data - is also a weakness. Most of the data are peripheral to traditional methods of patent valuation, such as market value, and date from the 1990s, so are only a trailing indicator of patent activity. The book's conclusions do not adequately reflect recent developments, including US court decisions that have narrowed patent scope, the opensource software movement and global pressures to limit software and medical patents.

Patent Failure focuses narrowly on financial value and costs of patents as private-property assets of publicly traded corporations. But patents serve other objectives that deserve greater attention. They are part of a dynamic, global intellectual-property system that drives innovation by balancing the exclusive rights of creators against the ability of others to access and copy creative works. The social benefits of the patent system, as it has evolved over the centuries, include promoting publication as an alternative to secrecy, rewarding investment in research, expanding international trade, allowing individual freedom and control over creative activities, promoting innovation races, helping innovators break into an established market allowing well-managed companies to supplant poorly managed competitors, and facilitating collaboration and technology transfer between public and private organizations. These benefits are undervalued or ignored in the book's financial calculations, and they contradict its conclusion of patent failure.

The book uses lively anecdotes and analogies, but this is ironic because the authors criticize other writers for relying on anecdotal information. And they overstate their case that patents would work better if they were more like real estate or copyright. The recent collapse in the real-estate market suggests that particular system is no panacea. And the authors' favourable view about the clarity of copyrights in the entertainment industry ignores frequent disputes over who owns rights to movies and music.

Patent Failure sets out in the right direction by comparing the corporate benefits of patents to their overall social costs, based on empirical data. And the book's conclusion may be sound, that the patent system would work better with clearer boundaries defined by patent claims. Ultimately, the book raises good questions, but leaves many unanswered.

Michael Gollin is a partner in the patent group at Venable LLP, 575 7th Street NW, Washington DC 20004, USA. He is author of Driving

Innovation: Intellectual Property Strategies for a Dynamic World.

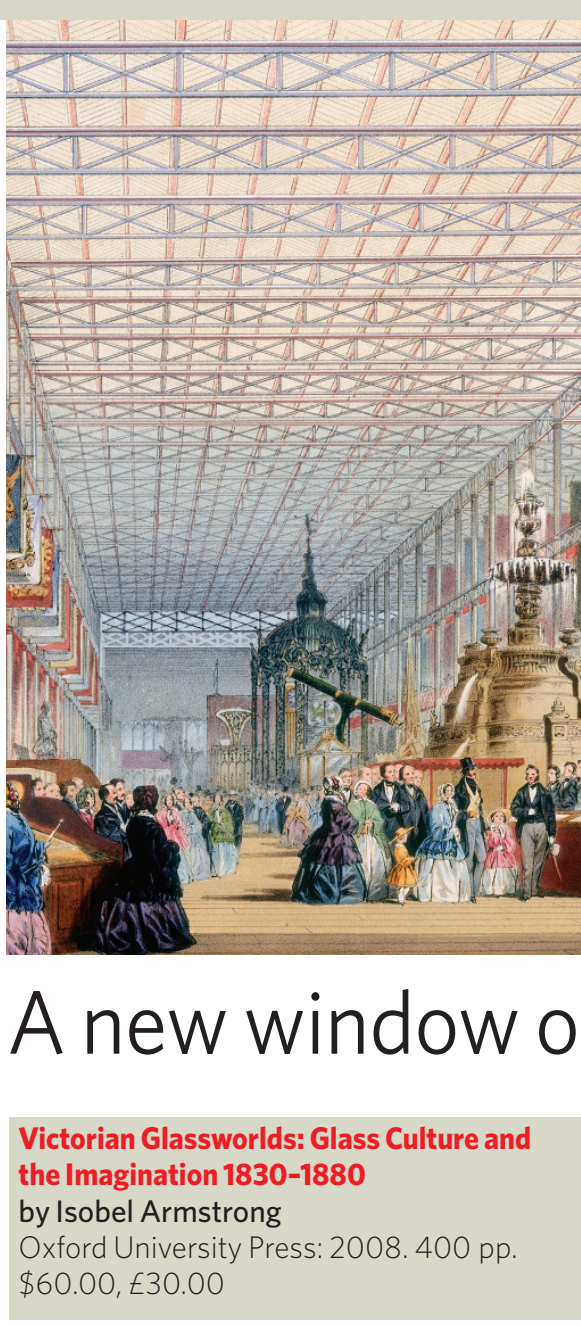

Robert Lucas Chance was a man of unpredictable temper. The method of mass-producing artisan-blown cylinder glass pioneered at his factory near Birmingham, UK, in the 1830 s was similarly prone to fiery eruptions, with coal firing difficult to control, and flames flashing unexpectedly out of the furnace when the molten glass was ready to be blown. Chance's name became synonymous with glass production in the nineteenth century, just as Hoover or Dyson are with vacuum cleaners today, and was peculiarly apt for the precarious nature of his business. The residual instability of the process, a contradictory amalgam of modern and archaic working practices, was made tangible in every sheet of cylinder glass by the traces of breath from individual blowers.

Chance's new processes nonetheless increased efficiency, facilitating the mass production of sheet glass and the manufacture of individual panes up to three metres square. The earlier Crown glass could reach a diameter of only half that, and was in a wasteful circular form. Historian Isobel Armstrong argues that Chance helped bring into being "an environment of mass transparency... never before experienced".

The Victorian age embraced the new possibilities of cheap glass. The middle class developed a craze for popular microscopy, while Chance Brothers and Company glazed the shimmering, gargantuan Crystal Palace (pictured) that housed London's Great Exhibition in 1851. The Victorians developed distinctive responses to this tantalizing material, from the bourgeois consumerism induced by the enticements within shop windows to the targeted window-breaking by working-class political activists. Victorian expansionism ensured that such responses extended across the oceans, safeguarded by lighthouses also glazed with Chance glass.

Victorian Glassworlds contends that technologies change experience. The widespread availability of full-length mirrors, particularly the fashionable cheval-glass mirror, altered how people perceived their bodies and prompted new ways of thinking about the nature of individual identity. London's Royal Coburg Theatre (now The Old Vic) installed a huge array of mirrors called a looking-glass curtain behind its stage in 1822. Audiences spent performances gleefully waving at themselves or ogling their superiors in more expensive seats, transforming themselves into performers and inducing an illusion of social unity.

Meanwhile, cylinder glass made possible the massive conservatories developed by John Claudius Loudon and Joseph Paxton in the 1830s and 1840s, such as Paxton's famous example at Chatsworth in Derbyshire. They allowed botanical specimens from across the expanding British empire to be grown despite the inclement weather, and forced more familiar flora to bloom out of season. Paxton's conservatory inspired his design for the Crystal Palace. Its success led him to propose placing much of central London under a ten-milelong enclosed glass atrium known as the Great Victorian Way. Although it was never realized, this visionary scheme shows the potential for 